\title{
PNOC Gene
}

National Cancer Institute

\section{Source}

National Cancer Institute. PNOC Gene. NCI Thesaurus. Code C118219.

This gene is involved in the modulation of both pain and locomotion. 